\title{
Artigos \\ Tradição, herança e reprodução familiar: o capital econômico e as redes de parentesco na construção de um político jovem
}

\author{
Pedro Jorge Chaves Mourão* \\ Jesus Marmanillo Pereira**
}

\section{Resumo}

Sob o viés da antropologia política, buscou-se analisar o processo que fornece base para campanha do ex-deputado estadual do Ceará Tomás Antônio de Albuquerque Paula Pessoa Filho, conhecido também como Tomás Filho Figueiredo. Produzimos assim uma etnografia centrada nos aspectos vinculados à aquisição de um conjunto de capitais (sociais, econômicos e políticos) herdados e ampliação das bases políticas em função das estruturas de mediação, de redes de parentesco e relações interpessoais que auxiliaram no deslocamento da ação política do parlamentar, do interior do estado para a cidade de Fortaleza. Nesse viés, valendo-se das contribuições de autores como Landé(1977), Wolf(2003), Barreira(2006), Grill(2008), Reis(2015) foi considerado um conjunto de fontes compostos por declarações, diálogos, observação direta e pesquisa documental vinculado ao estudo da trajetória política do parlamentar.

\section{Palavras-chave}

Parentesco. Mediação. Empreendimento político.

\begin{abstract}
Under the viewpoint of the political anthropology, the intention was to analyze the process that provides a foundation for the campaign of Ceará state's former congressman, Tomás Antônio de Albuquerque Paula Pessoa Filho, also known as Tomás Filho Figueiredo. I have thus created an ethnography centered on aspects linked to the acquisition of an inherited group
\end{abstract}

\footnotetext{
* Pedro Jorge Chaves Mourão é doutorando pelo Programa de Pós-Graduação em Sociologia (PPGS) da Universidade Estadual do Ceara (UECE). E-mail: pjmourao_cs@hotmail.com.

** Jesus Marmanillo Pereira é professor do Programa de Pós-Graduação em Sociologia (PPGS) da Universidade Federal do Maranhão (UFMA) e do Curso de Licenciatura em Ciências Humanas / Sociologia (Campus Imperatriz). E-mail: jesusmarmanillo@hotmail.com .
} 
of capitals (social, economic and political) and the amplification of political bases focused on structures of mediation, kinship networks and interpersonal relationships that helped in the displacement of the congressman's political action from the countryside of the state to the city of Fortaleza. With this point of view, based on the contributions of authors such as Landé (1977), Wolf (2003), Barreira (2006), Grill (2008), Reis (2015), I have considered a set of sources composed by declarations, dialogs, direct observation and documental research linked to the study of the congressman's political trajectory.

\section{Keywords}

Kinship; Mediation; Political Development.

\section{Introdução}

Como é possível pensar as participações e preponderâncias dos capitais econômicos e políticos no processo de construção de uma campanha eleitoral? Qual o papel das redes de parentesco e mediação para a ampliação da área de influência política de um candidato? Partindo dessas questões, o presente artigo compõe-se de uma etnografia com a qual se buscou problematizar e explorar a hipótese a respeito da importância dos capitais acumulados e das redes de parentesco e mediações como base para a ativação de determinados repertórios de intervenção política, ou seja, delinear uma interpretação sobre a transferência e construção da influência política de Tomás Figueiredo Filho nos municípios do interior para Fortaleza.

Nesse sentido, buscou-se pensar a campanha política dele não apenas como mobilização do tempo presente ou fruto de um dom político, mas conectada a uma lógica de reprodução política familiar. Tais indagações estão diretamente vinculadas a um conjunto de estudos colocados por Grill (2008, 2004, 2005), quando enfatiza a importância da compreensão e análise dos agentes sociais, de suas propriedades, bases sociais, das relações de reciprocidade, parentesco e deslocamentos nos espaços sociais e políticos. Em sintonia, também, com as análises de Barreira (2006a, 2006b), o artigo articula conceitos dedicados à compreensão dos mecanismos de dádivas, mobilizações de capitais e estratégias de dominação erguidas na hegemonia. Munidos desses referenciais, analisou-se a construção da campanha política do parlamentar, considerando, assim, alguns determinantes econômicos e sociais da divisão do trabalho político cuja importância analítica é, justamente, a de não naturalização dos mecanismos sociais que produzem 
e reproduzem determinadas classificações no campo político (BOURDIEU, 2007a).

Uma especificidade dessa etnografia é o fato de ter sido fruto de um processo coletivo em que não houve uma escrita simultânea, mas que resulta de um processo de diálogo entre pesquisadores de diferentes estados (Ceará e Maranhão), no qual a divisão de trabalho e socialização de fontes e referenciais foi algo fundamental para a produção do texto. Por meio de um conjunto de fontes ${ }^{1}$ composto por entrevistas com o candidato e membros de sua equipe, observação direta e registros fotográficos e bibliografias afins, foram elencadas algumas reflexões que podem ser enquadradas em dois aspectos: 1) condicionantes sociais, econômicos e redes de parentesco, que deram base para a campanha do referido parlamentar; e 2) processos de operacionalização da rede e do papel mediador na construção e ampliação espacial da base política do parlamentar.

\section{Parentesco e monopólio dos profissionais}

Como percebe Bourdieu (2007a), o sucesso no jogo político está condicionado, de alguma forma, tanto à capacidade de concentração dos meios de produção política quanto à aquisição de um habitus político, ou seja, "requer um corpus de saberes específicos produzidos e acumulados pelo trabalho político dos profissionais do presente e do passado (...) envolvendo assim o domínio de uma linguagem especifica." (p.169)

No caso aqui analisado, trata-se do ex-deputado estadual (pelo PSDB) Tomás Figueiredo Filho, que, segundo site ${ }^{2}$ da AL-CE, nasceu em Fortaleza, em 25 de agosto de 1981. O referido parlamentar é filho de Tomás Figueiredo, ex-prefeito de Santa Quitéria, e de Cândida Figueiredo, ex-deputada Estadual (PSDB). É também neto de Chico Figueiredo, exdeputado estadual, e sobrinho de Alexandre Figueiredo, ex-deputado estadual (PMDB), que até a finalização deste artigo era conselheiro do

\footnotetext{
1 A pesquisa de campo e os dados coletados no estado do Ceará foram desenvolvidas por Pedro Jorge Chaves Mourão.

${ }^{2}$ Informações preliminares sobre as biografias foram retiradas do perfil dos deputados no site da Assembleia Legislativa do Estado do Ceará. Disponível em: <http://www.al.ce.gov.br/ Deputados $/$ perfil.php?tabela=Deputados\&codigo=48>. Acesso em fevereiro de 2018 .
} 
Tribunal de Contas do Estado do Ceará.

Sobre os usos do passado e a formação de um habitus primário, Mourão e Pereira (2012) destacaram a importância da inserção do agente em um conjunto de práticas familiares que fortalecem a coesão, a reprodução e a manutenção de capitais políticos e da identidade política da tradição familiar vinculadas ao deputado. ${ }^{3}$ Essa relação entre o agente e sua estrutura familiar ou grupo primário não pode ser dissociada de um estudo mais detalhado sobre a questão do parentesco na política. Para Grill (2008), esse aspecto ganha legitimidade e eficácia tanto para os agentes quanto para suas famílias, já que geralmente expressam uma convergência entre itinerários individuais e os trunfos derivados dos laços familiares. Assim, o que entendíamos como "ancestralidade", que ajudava a explicar a formação de um determinado habitus, é pensada aqui como um importante elemento para a compreensão da construção da imagem autônoma do agente, segundo uma lógica de estudos de parentesco, de alianças e de redes. Tal constatação pode ser observada quando verificamos o seguinte trecho do lançamento da campanha de Tomás Filho na eleição para a Prefeitura de Santa Quitéria:

“Juventude, tradição, conhecimento e empreendedorismo: estes
são os principais elementos que formam o perfil político de Tomás
Figueiredo Filho. Com apenas 28 anos, é um dos mais jovens e
atuantes parlamentares do Ceará. Sua família tem longa tradição
na luta pela melhoria das condições de vida dos cearenses. O
dom da política foi herdado de seu avô paterno, o saudoso
Chico Figueiredo, reconhecido pelo trabalho na criação do curso
superior em Medicina Veterinária da Universidade Estadual do
Ceará (UECE) e na construção do açude Edson Queiroz, em Santa
Quitéria. Posteriormente, seus pais também tiveram e mantém
até hoje importantes participações na política estadual: Cândida

\footnotetext{
${ }^{3}$ Os autores explicam que, assim como uma "empresa política", a família apresentou-se como uma poderosa estrutura de apoio para o jovem aspirante a legislador, fosse como espaço de aprendizagem e socialização de códigos, como espaço de aquisição de recursos materiais, como um emprego, e também como capital simbólico capaz de definir espaços, aliados, inimigos, prestigio e trunfos políticos. Através dos usos do passado, ou seja, da reivindicação de uma origem familiar, o agente ativou não só um pertencimento familiar, mas também o tempo em um espaço de inserção política.
} 
Figueiredo foi deputada estadual e presidente das Centrais de Abastecimento do Ceará (Ceasa), e Tomás Figueiredo foi prefeito de Santa Quitéria por três gestões" (FIGUEIREDO FILHO, 2010). ${ }^{4}$

Tal apresentação sustenta-se na convergência das características da tradição familiar dos Figueiredos com as características pessoais e técnicas do próprio agente: ser um dos parlamentares mais novos, elevada qualificação acadêmica, experiência internacional e especializada nas áreas empresarial e de Direito ${ }^{5}$. Nesse sentido, Grill (2004) explica que a relação de parentesco produz crédito de notoriedade pessoal e um processo de investidura da instituição familiar, ritualizando uma história política "simbolizada pelas etiquetas, mas simultaneamente dependente das redes de relações no partido, personalizadas pelas lideranças, e dos trunfos simbolizados pelos líderes carismáticos." (GRILL, 2004, p. 160)

A citação de Figueiredo Filho (2010) contém, assim, uma possibilidade de análise sobre parentesco, já que possui os seguintes pontos: 1) as operações de maximização do reconhecimento desfrutado da família, valorizando os feitos dos fundadores e inserção da mesma na memória política local e 2) a diferenciação entre os pares - construída com base na familiaridade do meio político e precocidade no contato com os rituais de linguagem que marcam o funcionamento da esfera de socialização (GRILL, 2008).

Os dois primeiros pontos caracterizam um tipo de convergência que pode ser pensada em termos de um rito de instituição (BOURDIEU, 2008), cuja função seria notificar uma determinada identidade, atribuindo a esta uma espécie de justificativa para a própria existência da candidatura do agente. Para Canedo (1994), a importância da análise desses ritos reside no fato de os mesmos reativarem não apenas a memória familiar, mas também da população, preparando-a para o ritual maior das eleições que se sucedem em tempo marcado.

\footnotetext{
${ }^{4}$ Referência: FIGUEIREDO FILHO, Tomás. Tomás Figueiredo 4545. 2010. Disponível em: https://www.flickr.com/people/tomasfigueiredo4545/ . Acesso em 24 de fevereiro de 2018.

${ }^{5}$ Embora se fale de "dom da política", observamos que ocorreu um processo de formação de habitus, expresso inclusive na valorização nesse tipo de "tradição moderna", na qual Tomás Filho busca enquadrar-se e utilizar nas relações sociais com o público em geral. Nesse sentido, considerar o uso da estrutura familiar e da história é um exercício fundamental, a fim de não naturalizarmos os mecanismos sociais que produzem e reproduzem determinadas classificações no campo político.
} 
Além desses aspectos, é possível destacar um terceiro ponto, pois as esferas da política e da família são estreitamente misturadas, possibilitando uma rede de parentesco com a capacidade de oportunizar movimentos e projeção do agente sobre diferentes espaços sociais e políticos. Tais redes podem ser problematizadas na narrativa do próprio agente, destacada no seguinte diálogo entre o parlamentar e o pesquisador Pedro Jorge Chaves Mourão:

TOMÁS: (...) foi aí então que eu comecei a expor essa minha vontade e a gente (buscou) consultar as diversas pessoas que nos apoiaram...

PEDRO JORGE: quem?

T: Lideranças no interior do estado, pessoas que até hoje nos acompanham como o Zé Romano do Nascimento, o Zezinho de Ubajara, que é um empresário lá da região de Ibiapaba que já foi candidato a prefeito, já foi vice-prefeito, os nossos próprios correligionários, que foi a base política em que meu pai ingressou na vida pública. Ele era fora da política e quando ele ingressou foi sendo candidato a prefeito e depois prefeito em Santa Quitéria, então a gente tem em Santa Quitéria a nossa principal base politica apesar da família ser de Sobral, ter negócios em Sobral e ter se desenvolvido em Sobral e meu avô ter feito a vida política dele toda na política de Sobral. Já o meu pai ingressou (na política de) por Santa Quitéria e a gente tem um carinho todo especial e tem hoje o nosso berço político em Santa Quitéria. Então a gente consultou nossos correligionários e os mais diversos amigos que nos orientam e que compartilham conosco das alegrias e das dificuldades e a gente compartilhou isso e chegou à conclusão que eu seria uma boa opção e eu abracei aquela causa com todas as minhas vontades, com todas as minhas forças. [Destaque meu]. ${ }^{6}$

Assim, além de apontar as condições sociais de inserção na política, no qual o capital social (BOURDIEU, 2007a) acumulado pelos pais passa a ser apropriado pelo filho, o trecho sinaliza também que as relações de troca que se estabelecem entre os apoiadores e o deputado têm como base a credibilidade, caracterizando uma situação na qual "o homem

\footnotetext{
${ }^{6}$ Trata-se de um registro do caderno de campo produzida pelo pesquisador Pedro Jorge Chaves Mourão.
} 
político retira a sua força política da confiança que um grupo põe nele" (BOURDIEU, 2007a, p.188). Em outros termos, tem-se um conjunto de relações interpessoais que garantem uma base. Se tomada nos termos de Landé (1977), essa pode ser pensada como um conjunto de relações diáticas nas quais os indivíduos estão ligados por relações pessoais diretas. $\mathrm{Na}$ perspectiva de compreensão da construção de uma rede, tais afinidades podem ser analisadas como um conjunto no qual o agente é o ponto central de onde emanam as várias relações pessoais diretas.

Segundo Scherer-Warren (1995), uma rede indica não apenas a ligação entre pessoas, mas também o intercruzamento de ligações entre elos e suas relações sociais. Sendo um termo útil para indicar as relações entre indivíduos em contextos de vizinhança, amizade, parentesco e outros importantes aspectos para a compreensão dos quase grupos, ou seja, das redes formadas, interpretadas como um conjunto finito de relações estruturadas em torno de um ego-projetadas e utilizadas para a realização dos interesses e objetivos políticos do mesmo (MAYER, 2010). Sobre a noção de rede, é importante ainda considerar as ponderações feitas por Reis quando nota que:

"Vários autores se preocuparam em redefinir a noção de redes de modo a torná-la compatível seja com as sociedades ditas não ocidentais seja com a complexidade Moderna. Alguns buscaram potencializá-la enquanto instrumento operacional à apreensão das práticas e relações de indivíduos e grupos. É o caso de perspectivas que tentaram romper com a abordagem de cunho estrutural, que propunha a coexistência, no espaço social, de diferentes esferas de atividades, compondo um sistema que poderia ser estudado a partir de critérios formais de ligação de seus componentes". (REIS, 2015, p.76).

Seguindo essa orientação, observamos que um indicativo inicial para chegarmos a algum ponto da rede de Tomas Filho - foi observado no relatório da prestação de contas da campanha eleitoral ${ }^{7}$ dele junto ao Tribunal Regional Eleitoral do Ceará (TRE-CE) em 2006. Por meio desse, chegamos aos nomes dos financiadores de sua campanha e aos valores creditados, como é possível observar na Tabela 1.

\footnotetext{
${ }^{7}$ Disponível no Site pertencente ao projeto da organização não governamental "Transparência Brasil."
} 
Tabela 1 - Relação de nomes de doadores e valores doados para a campanha eleitoral de Tomás Filho (2006)

\begin{tabular}{|c|c|c|}
\hline Nome & CGC & Doações \\
\hline $\begin{array}{l}\text { TOMAS ANTONIO ALBUQUERQUE DE } \\
\text { PAULA PESSOA FILHO }\end{array}$ & 618.824 .453 & $\mathrm{R} \$ 66.000,00$ \\
\hline POSTO BALANÇA LTDA & 076.048 .530 & $\mathrm{R} \$ 16.000,00$ \\
\hline $\begin{array}{l}\text { TOMAS ANTONIO ALBUQUERQUE DE } \\
\text { PAULA PESSOA }\end{array}$ & 059.465 .733 & $\mathrm{R} \$ 14.000,00$ \\
\hline $\begin{array}{l}\text { CANDIDA MARIA SARAIVA DE PAULA } \\
\text { PESSOA }\end{array}$ & 111.158.155 & $\mathrm{R} \$ 14.000,00$ \\
\hline ANTONIO TORRES NETO & 150.863 .051 & $\mathrm{R} \$ 3.000,00$ \\
\hline Total de doações & & $\mathrm{R} \$ 113.000,00$ \\
\hline \multicolumn{3}{|c|}{ Doadores do comitê } \\
\hline CGC inválido & 000.000 .010 & $\mathrm{R} \$ 2.129,33$ \\
\hline DEUSIMAR LUCENA GOMES & 131.662 .304 & $\mathrm{R} \$ 2.000,00$ \\
\hline TELMA CAVALCANTE MOTA & 051.513 .849 & $\mathrm{R} \$ 500,00$ \\
\hline Total de doações ao comitê & & $\mathrm{R} \$ 4.629,33$ \\
\hline
\end{tabular}

Fonte: Às Claras $2006^{8}$

Entre outras coisas, tal documento indica que o maior doador foi o próprio Tomás Filho, e na sequência a empresa Posto Balança Ltda. que, segundo Paiva Mororó (2006), seria pertencente ao avô do candidato pesquisado. ${ }^{9}$ Já os pais dele doaram $\mathrm{R} \$ 14 \mathrm{mil}^{10}$ cada um para a campanha do filho. Com base nessas informações, levantou-se, para Tomás Filho, a questão sobre a doação do Posto Balança e apoiadores, resultando no seguinte diálogo entre o parlamentar e o pesquisador:

T: É da [minha] família.

PJ: Mas pertence a alguém especificamente?

\footnotetext{
${ }^{8}$ Após a exclusão do site “http:// www.asclaras.org.br/@index.php?ano=2006" (As claras), a pesquisa valeu-se de uma cópia do conteúdo do site armazenada no drive https:/ / documents. tips/documents/quem-financiou-tomas-figueiredo-nas-eleicoes-2006.html.

${ }^{9}$ Tal posto de gasolina, situado na margem da rodovia estadual CE-257, nas mediações de Santa Quitéria, foi herdado após o falecimento do avô.

${ }^{10}$ Na época o salário mínimo no Brasil era $\mathrm{R} \$ 350,00$. Ver http://www.planalto.gov.br/ ccivil_03/_ato2004-2006/2006/Lei/L11321.htm Acesso em 3 de março de 2012.
} 
T: Não sei quem são os sócios do posto, mas é uma empresa da família, que fica lá em Santa Quitéria...

PJ: Você pediu esse dinheiro para eles?

T: Claro.

PJ: Mas para eles, quem?

T: Como a empresa é familiar foi uma coisa natural...

PJ: Mas a quem pertence?

T: Acho que é do meu pai ou da minha mãe, não sei te dizer quem é o sócio, mas é da família.

PJ: O doador seguinte é seu pai, depois sua mãe... e Antonio Torres Neto, quem é?

T: Antonio Torres Neto é um contador que trabalha conosco e que sempre trabalhou...

Antes de identificar e tentar mapear a rede de relações, é importante problematizar a dualidade pesquisador-objeto, já que, entre outras coisas, a citação $^{11}$ traz uma interessante situação de interação entre esses dois agentes. É possível observar um comportamento insistente na busca de respostas que apontem o nome dos proprietários do posto de gasolina e detentores do capital econômico. Por outro lado, o entrevistado responde de forma curta e evasiva, fazendo com que as questões continuem sobre os outros nomes presentes na Tabela 1. Tal contexto de interação é, antes de tudo, uma relação humana, na qual as regras e o modo como são conduzidas se tornam passíveis de negociação, ou seja, o vínculo pesquisador-objeto, as hierarquias e os diferentes tipos de capitais acumulados, pelos dois, interferem diretamente nas respostas e interações (BOURDIEU, 1999) ${ }^{12}$.

${ }^{11}$ Trata-se de um registro do caderno de campo produzida pelo pesquisador Pedro Jorge Chaves Mourão.

${ }^{12}$ Segundo o autor, geralmente é o pesquisador que inicia o jogo e estabelece a regra do jogo, atribuindo a entrevista de maneira unilateral e sem negociação prévia, os objetivos e hábitos, às vezes mal determinados, ao menos para o pesquisado (BOURDIEU,1999, p. 695). 
Um dado interessante é o fato de citar Antonio Torres como contador "que trabalha conosco e que sempre trabalhou". Tal afirmação indica a presença de um especialista cujo recrutamento parece ligado às questões de confiança erguida sobre uma antiga relação e divisão do trabalho entre os agentes (contator e família do parlamentar). Trata-se, também, de uma afirmação que indica o caráter coletivo de Tomás Filho quando diz: "é um contador que trabalha conosco....". Reafirma assim que a relação entre o contador e a campanha está diretamente vinculada aos aspectos da estrutura de parentesco do parlamentar.

Segundo a folha de pagamento da AL-CE de30 dejaneiro de 2009, Antonio Torres Neto foi funcionário comissionado da AL-CE, tendo trabalhado na Procuradoria da casa, pois consta o seu nome no referido documento ${ }^{13}$ do órgão público. Esse indício aponta uma possível troca de favor material e simbólica. Tanto Deusimar Lucena Gomes como Telma Cavalcante Mota aparecem nos documentos pesquisados (no site Às $\mathrm{Claras}^{14}$ ) como doadoras em 2006 para diversos candidatos do PSDB, com valores iguais aos doados a Tomás Filho. Isso pode ser compreendido pela natureza desse tipo de doação feita ao comitê eleitoral partidário. Tais doações são direcionadas para apoiar o partido no financiamento das campanhas dos candidatos deles e não especificamente a um candidato.

Durante a pesquisa, identificou-se, por meio de documentos digitalizados disponíveis na internet ${ }^{15}$, que Deusimar Lucena Gomes prestou serviço como contadora na Associação de Municípios e Prefeituras do Estado do Ceará (APRECE). Instituição cujo presidente para o exercício do biênio 2005/2007 era Antônio Carlos Torres Fradique Accioly, filiado ao PSDB. Essa informação sugere a possibilidade de ligação de fidelidade entre o partido, o presidente da APRECE-filiado ao PSDB e a funcionária

\footnotetext{
${ }^{13}$ Disponível em: <http://www.al.ce.gov.br/folha/ANEXO01.txt> Acesso em 14 de maio de 2012.

${ }^{14}$ Disponível em: <http://www.asclaras.org.br/@index.php?ano=2006> Acesso em 19 de maio de 2012. (Embora o link tenha sido removido, meses após a pesquisa, foi realizado um backup do conteúdo no seguinte drive https:/ / documents.tips/documents/quem-financioutomas-figueiredo-nas-eleicoes-2006.html ).

${ }^{15}$ Disponível em:<http://aprece.org.br/site/downloads/BALANOMENSAL_25221260810465. pdf $>$ Acesso em 23 de maio de 2012.
} 
terceirizada Deusimar Lucena Gomes. Já Telma Cavalcante Mota é apresentada em documentos ${ }^{16}$ do Tribunal de Contas dos Municípios do Ceará (TCM-CE) como funcionária terceirizada que prestou serviço para a Prefeitura de Horizonte.

Além de sinalizar a existência de relações de parentesco na política e a efetividade das redes, tais informações apontam para o que Bourdieu (2007b) chamava de "conversão de capitais": a conversão do capital econômico para capital político, do capital político para o capital social e vice-versa. As estratégias de reconversão do capital operam no sentido de buscar transformar um determinado capital em outro, passando a utilizálo como ferramenta em outro campo social distinto do campo inicial onde esse era utilizado. Através do capital econômico acumulado por Tomás Filho para sua candidatura, ele sustenta uma estrutura logística articulando apoiadores para divulgar e balizar sua campanha eleitoral e, assim, angariar votos e instrumentalizá-los na forma de capital político.

Tanto os valores quanto os rearranjos e ativação das redes de relações interpessoais, as informações vistas até aqui, também nos remetem para o raciocínio de Barreira (2006a), quando diz que "a vitória não tem preço, ou em outras palavras, tem um preço muito elevado" (p.154), e explica a sobreposição do capital econômico sobre o capital político. Para esse autor, há uma mistura entre práticas tradicionais e usos modernos de obtenção do voto caracterizados, principalmente após 1932, por meio das trocas de favores, barganhas, gratificações, constituindo um sistema de dádivas criador de obrigações que devem ser retribuídas. Por meio da análise dessa cultura política, é possível notar uma relação de troca de favores políticos e benefícios econômicos em diferentes escalas, incluindo desde a pessoa que é indicada para determinado cargo até os empresários que investem na disputa por votos.

Uma reflexão deve ser feita: os valores gastos em campanha são maiores do que os valores acumulados na função de legislador? O cálculo para essa resposta é relativamente simples. Durante a campanha, o candidato pesquisado informou oficialmente ter gasto $\mathrm{R} \$ 113.000,00$ somado aos

\footnotetext{
16 Disponível em: <http://www.tcm.ce.gov.br/transparencia/index.php/municipios/ nempenho/cod_neg/06131662304/mun/068/versao/2008/despesa/33903600/cod_dig/36/ de_elemento_od/Outros+Servi\%E7os+de+Terceiros+-+Pessoa+F\%EDsica> Acesso em 12 de outubro de 2015.
} 
$\mathrm{R} \$ 4.629,33$ vindos da doação ao comitê eleitoral, totalizando $\mathrm{R} \$ 117.629,33$. A remuneração do parlamentar estadual na época era de $\mathrm{R} \$ 12.384,07$ mais auxílios e verbas referentes ao desempenho parlamentar. A soma total dos salários de um parlamentar durante um mandato é de aproximadamente $\mathrm{R} \$ 643.971,64$, valor que ultrapassa em muito a estimativa de investimento feito pelo pesquisado.

Para ser candidato, Tomás Filho apresentou não só a disposição, a forma de conduta, saberes, práticas e determinadas características acumuladas durante as diversas socializações no decorrer do tempo de sua vida, que passaram a ser convertidas em moeda de confiança entre ele e os pais, e entre ele e os "amigos da família", mas também um vasto investimento econômico que lhe possibilitou entrar no campo político representando a família e suas bases políticas. Tal constatação nos possibilita pensar em termos de combinação e reconversão de capitais econômicos, culturais e sociais em capitais políticos, e também na importância dos vínculos de parentesco, amizade e confiança, sinalizando que não se trata de uma situação ideal na qual há um ou outro recurso utilizado, mas sim a preponderância e/ ou combinação de vários repertórios e estruturas.

Para avaliar tais aspectos, é importante considerar que, além do Posto Balança, outros nomes citados na tabela apontam a mobilização da estrutura familiar em torno da candidatura de Tomás Filho e sustentada sobre uma rede egocentrada. Por exemplo, o primeiro da lista Tomas Antônio Albuquerque de Paula Pessoa é o próprio Tomás Filho, Tomas Antônio Albuquerque de Paula Pessoa é o pai do parlamentar; Cândida Maria Saraiva de Paula Albuquerque é a mãe do candidato; e Antônio Torres Neto é o contador de confiança da família. Outra forma de exemplificar e problematizar combinação e efetivação dos capitais econômicos em relação aos vínculos de parentesco e amizade é por meio do depoimento de Cândida Maria Saraiva de Paula Pessoa ${ }^{17}$ (conhecida também como Cândida

\footnotetext{
${ }^{17}$ Casada com Tomás Antônio Albuquerque de Paula Pessoa, são pais de Fátima Laurênia, Joana Carolina e Tomás Filho. Cândida Figueiredo começou sua vida profissional como Engenheira Civil na COHAB em 1982. Eleita Deputada Estadual para a Legislatura de 1995/98, já desempenhava desde 1993 atividades políticas como Primeira Dama do Município de Santa Quitéria, onde seu marido Tomás Figueiredo era Prefeito. Presidente da Comissão de Defesa Social, fez importantes ações voltadas à segurança pública e à defesa do cidadão, sempre buscando a integração social no sentido de prevenir ou reduzir os índices de violência e criminalidade no Estado do Ceará. (CEARÁ, 2011, p.38)
} 
Figueiredo), que explica sua campanha política em 2002 da seguinte forma:

“Em 2002, sonhei que poderia me eleger só com o apoio de amigos, mas isso não foi suficiente para novamente galgar uma cadeira na Assembleia Legislativa. Sabíamos das nossas dificuldades nas bases eleitorais, pois nos faltava o respaldo financeiro para montar uma estrutura mínima de campanha, E assim mesmo, sozinha, contando com os amigos fiéis, conseguimos 23.434 votos. O preço destes votos foi a amizade, o valor do conceito construído e da credibilidade. Isto é ou não é fantasia?". (SANTOS; LEITÃO, 2002, p.136). [Destaque nosso].

Mesmo pertencendo a uma família tradicional cujo marido é Tomas Antônio Albuquerque de Paula Pessoa (ex-prefeito de Santa Quitéria nos mandados compreendidos entre os períodos de 1993-1996 e de 20002008, filho do deputado Francisco Figueiredo de Paula Pessoa ${ }^{18}$ e irmão do

${ }^{18}$ Chico Figueiredo, como era chamado pelos amigos, integrava a Quarta geração do Senador Francisco de Paula Pessoa, conhecido como O Senador dos Bois. Nasceu em Sobral/CE a 13.07.1921 e faleceu em Fortaleza a 10.12.1990. Graduou-se engenheiro agrônomo pela Escola de Agronomia do Ceará, em 1944. Casou-se com Benedita Maria Albuquerque de Paula Pessoa, filha de Francisco das Chagas de Albuquerque e Sousa, que durante muito tempo foi Prefeito de Pacatuba e era irmão do então Governador Faustino de Albuquerque. Fundou e dirigiu o Sindicato dos Bancários de Sobral, época em que se elegeu vice-presidente da Federação Norte-Nordeste dos Bancários, tendo sido seu presidente interino. Ainda muito jovem iniciou suas atividades políticas nas hostes do líder político regional Deputado Francisco de Almeida Monte, sogro do ex-Governador Parsifal Barroso, em cujo governo Francisco Figueiredo ocupou o cargo de Secretário de Agricultura, Abastecimento, Indústria e Comércio. Fundou a Lassa - Laticínios Sobralense S/A. Ainda no campo empresarial, Francisco Figueiredo fundou e dirigiu até seu último dia de vida as empresas ERCASA - Empresa Rural Caraúbas S/A, ERSSA - Empreendimentos Rurais de Sobral S/A, PIASA - Piabas Agropecuária S/A, CONASA - Conceição Agropecuária S/A, COPAS - Companhia Produtora de Algodão e Suínos e Posto Balança Ltda. Nas décadas de 70 e 80, 85 chegou a ser o maior produtor de algodão arbóreo do Ceará, sendo também, à época, o maior criador de gado bovino, com um rebanho de oito mil cabeças que produzia quase três mil bezerros por ano. Foi duas vezes Deputado Estadual. Dentre as suas muitas realizações como parlamentar destaca-se a construção do Açude Edson Queiroz em Santa Quitéria - gestão sua junto ao então Ministro Mário Andreazza - e a estadualização da Universidade do Vale do Acaraú (UVA). É longa a sua folha de serviços prestados e de feitos em prol da Zona Norte e do Ceará. Sua obstinação e determinação, seu espírito empreendedor e sua larga visão tornaram Chico Figueiredo, ao lado de outros sobralenses, um exemplo de homem público. (CEARÁ, 2003, p.83) 
ex-deputado Luís Alexandre Albuquerque Figueiredo de Paula Pessoa ${ }^{19}$ ), Cândida Figueiredo operacionaliza a "amizade" e "credibilidade" como importantes trunfos relacionados às lógicas de redes e mobilização de outros capitais. Em termos bourdianos, pode-se dizer que toda a estrutura familiar sinaliza uma transferência de capital social para capital político. Assim, mais que um dado concreto, a suposta ausência de capital econômico necessário para dar suporte a sua campanha eleitoral, a ativação das redes sociais instrumentalizadas em fidelidade se constituem como dado não por conta da veracidade das informações, mas devido aos sentidos empregados na fala da entrevistada.

Dessa forma, percebe-se que por trás de cada ação existe uma estrutura de valores construídos e ressignificadas no decorrer da história política particular que aos poucos foi tomando forma de costumes e hábitos coletivos. Tal estrutura pode ser analisada através da fala de outro informante que narrava o mesmo tema: "O pecado de todos não é pecado de ninguém." Quando determinadas práticas passam a ser vistas como "normais" por um grupo social, elas passam a ser institucionalizadas dentro do corpo de práticas socialmente aceitas naquele grupo. Exemplo disto são os mecanismos aqui descritos de prestação de contas utilizados pelos candidatos, nos quais podemos observar a distinção entre as normas legais e o modo de fazer política no cotidiano.

19 Segundo o site do Tribunal de Contas do Estado do Ceará, Nascido em Sobral, cursou o primário naquela cidade, transferindo-se para Fortaleza onde fez o secundário. Antes do curso universitário, estudou na Spaulding School, em Rochester, New Hampshire (EUA). É engenheiro agrônomo e bacharel em Direito, sendo pós-graduado em Direito Constitucional. No setor privado, fundou e dirigiu empresas de atividade agropecuária. Ingressou na políticapartidária, sendo eleito Deputado Estadual pela primeira vez para cumprir mandato de 1987 a 1991. Reelegeu-se para legislatura de 1991 a 1995. Foi empossado Conselheiro do Tribunal de Contas do Ceará em 29.06.95, após ser indicado por 10 partidos políticos representados na Assembleia Legislativa. Durante o biênio 1996/1997 foi vice-presidente do TCE e exerceu as funções de Presidente durante o biênio 1998/1999. Atualmente, além do devotado exercício profissional de Conselheiro decano, é Diretor-Presidente da Escola de Capacitação Ministro Plácido Castelo, do Tribunal de Contas do Estado do Ceará, e professor de Direito Administrativo da Universidade de Fortaleza - UNIFOR, escreve artigos e ministra palestras sobre temas variados de Direito Administrativo, notadamente sobre o Controle Externo da Administração Pública. Disponível em: <http://www.tce.ce.gov.br/institucional/ composicao-atual/29-presidencia/institucional/composicao-atual/37-luis-alexandrealbuquerque-figueiredo-de-paula-pessoa> Acesso em 10 de outubro de 2015. 


\section{Mediação e ampliação da influência política}

Durante a pesquisa, observamos os mapas do Ceará e de Fortaleza, emoldurados na parede da sala do pesquisado, na AL-CE. Neles havia pontos azuis, laranjas e verdes, marcando localidades que, segundo Gustavo Queiroz (chefe de gabinete, ex-colega de faculdade e amigo pessoal do pesquisado), representavam os locais onde estavam os votos e as lideranças que davam apoio à candidatura. De modo mais detalhado, a marcação simples com um círculo azul significaria a presença expressiva de eleitores de Tomás Filho, e pontos duplamente marcados indicam a presença de lideranças políticas apoiando o parlamentar.

\section{Fotografias 1 e 2 - Bases eleitorais de Tomás Filho no Ceará e em Fortaleza}

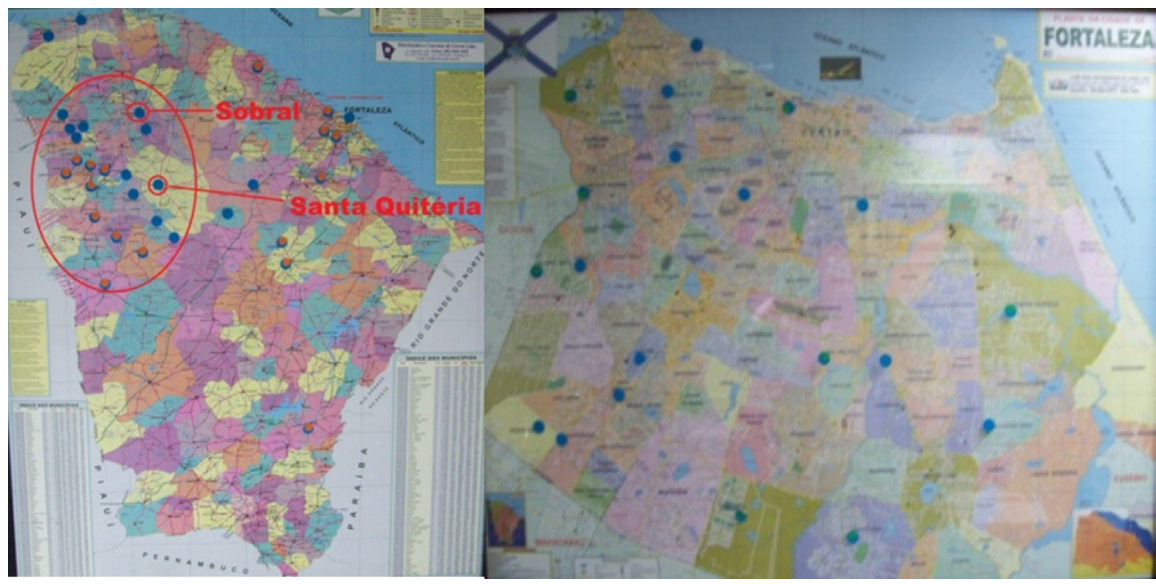

Nota: Detalhes em vermelho feitos pelo autor.

Fonte: Mourão (2012b).

Alguns detalhes são relevantes nos mapas: 1) a preocupação em diferenciar as bases eleitorais entre Fortaleza e o Ceará - no mapa do Ceará os pontos onde se localiza a maior quantidade de lideranças que apoiam Tomás estão na região em que seus pais atuaram como políticos, Santa Quitéria e proximidades; 2) a diferença do número de pontos duplamente marcados, indicação de lideranças entre Fortaleza e o restante do Ceará e 3) o número de lideranças apoiadoras superior no interior. Quantificando os pontos marcados, verificou-se que as localidades que votam em Tomás fora da capital são 33, ao passo que em Fortaleza são 20. Já o número de 
lideranças no interior é de 17, e em Fortaleza é de 7.

Tabela 2 - Relação de localidades e lideranças em Fortaleza e em Interior do Estado que apoiaram Tomás Filho

\begin{tabular}{|c|c|c|}
\hline & Localidades votantes & Lideranças \\
\hline Fortaleza & 20 & 7 \\
\hline Interior do Ceará & 33 & 17 \\
\hline
\end{tabular}

Fonte: Mourão (2012 b).

Apesar de todos os detalhes observados em campo, os números apresentados são um indício de que a base eleitoral de Tomás Filho possivelmente está ligada à ação política dos pais no interior do Estado, ou seja, aciona toda a estrutura familiar presente em Santa Quitéria e áreas circunvizinhas ${ }^{20}$, demonstrando a importância da compreensão das relações de reciprocidade, de parentesco e de uso das mesmas para ampliar os votos, alcançando outros espaços geográficos. Quando questionamos sobre os municípios que compõem a sua base de atuação política, obtivemos a seguinte descrição:

T: Santa Quitéria, Sobral, Região da Serra de Ibiapaba, principalmente a zona Norte a região do Vale do Acaraú, baixo Acaraú, município de Acaraú, Bela Cruz, Camocim, toda parte da Região Norte, essa é a atenção maior parte e também aqui na região metropolitana de Fortaleza, e como é que funciona? Em alguns lugares com apoio a vereadores e prefeitos do interior do Estado fazendo essa intermediação, abrindo aqui as portas, recebendo aqui, às vezes para um vereador do interior ou mesmo para um prefeito do interior vir a Fortaleza é um bicho de sete cabeças e nada melhor que um deputado com sua assessoria técnica para ajudar, facilitar a vinda de prefeitos e vereadores aqui, isso é uma forma também de por eles estarem lá no dia a dia com o eleitor facilitar a vida política do deputado. $\mathbf{O}$ deputado está lá representado pelo prefeito e vereador que está lá no dia a dia com as pessoas e também tenho uma atuação conceitual

\footnotetext{
${ }^{20}$ Segundo o Anuário do Ceará 2007-2008 (2007), podemos nomear as cidades do Ceará que compõem a base política de Tomás Filho da seguinte forma: Santa Quitéria, Camocim, Canindé, Carnaubal, Fortaleza, Frecheirinha, Hidrolândia, Ibiapina, Sobral, Tamboril, Tianguá, Ubajara e Varjota.
} 
no que diz respeito a políticas públicas, agi muito na questão do desenvolvimento econômico, da segurança alimentar, são pilares de ideia do meu mandato, segurança pública (alimentar) foi um tema que eu abordei de forma muito contundente.

Existe uma diferença na dinâmica da relação que Dona Cândida e Tomás Figueiredo pai mantinham com suas bases que se distingue da atuação política de Tomás Filho. O pesquisado logo buscou uma atuação política na Capital onde reside, enquanto as bases políticas de seus pais foram mantidas no interior. Contudo, essa ampliação espacial da influência e ação política da família ocorreu, em grande medida, por conta do papel de mediador desenvolvido pelo parlamentar. Por mediação entendemos aqui uma dinâmica similar à descrita por Wolf (2003) ao analisar as redes de relações que conectam determinadas localidades mexicanas às instituições nacionais, caracterizando relações entre indivíduos orientados para a comunidade e outros orientados para a nação.

Nesse viés, a citação sinaliza que o agente desempenhou o papel de mediador entre os políticos municipais institucionalizados (prefeitos e vereadores) e o Poder Executivo Estadual e Secretarias, concedendo suporte para o diálogo entre estes e as partes. A fala do pesquisado sugere que essa mediação e apoio às demandas dos políticos locais se estabelece na medida da capacidade representativa e do poder de influência desses em captar apoio político para o deputado bem como na capacidade de diálogo entre o deputado e o governo estadual vigente. Sobre essa estratégia de ampliação das redes de relações para outros locais geográficos, é importante também considerar a análise feita por Marcos Otávio Bezerra sobre a dinâmica da relação entre parlamentares federais e prefeitos.

“O vínculo entre parlamentares e prefeitos não é uma relação de mão única. Os parlamentares têm expectativas em relação às lideranças políticas que contam com seu apoio e empenho. Socialmente produzidas, estas expectativas obrigações mútuas que unem parlamentares e lideranças políticas locais estão, em grande medida, associadas às posições que estes agentes sociais ocupam no conjunto das relações políticas. (...) Em linhas gerais, os prefeitos esperam dos parlamentares que estes realizem pequenos favores, encaminhando seus interesses junto à burocracia governamental e, principalmente, consigam obter verbas (..) para a realização de investimentos nos municípios. (...) Parte da força do parlamentar frente aos prefeitos reside, assim, 
na possibilidade que o primeiro possui de viabilizar o acesso destes últimos às autoridades governamentais". (BEZERRA, 1999, p.121-122).

No entanto, a partir do caso aqui avaliado, podem-se agregar novos agentes na dinâmica das relações entre os campos políticos nacionais e locais. A acessibilidade material e simbólica ao poder público também é sugerida por Kuschnir (2000) como elemento de ligação entre os representantes e os representados. A mobilidade do político para se deslocar e traçar elos entre interesses diversos se mostra como ferramenta-chave para a atuação no cotidiano político. Em 2008, Tomás Filho estava em pleno exercício do mandato legislativo. Seu pai era prefeito de Santa Quitéria; e Francisco das Chagas Mesquita, ou Chagas Mesquita, era o candidato apoiado pelos Figueiredo de Paula Pessoa para a Prefeitura de Santa Quitéria-CE. Segundo o relato do pesquisado, os laços de fidelidade que tinham com Chagas Mesquita foram rompidos e outros candidatos apoiados não obtiveram vitória no pleito ou foram "cooptados" pela influência do grupo político do então governador Cid Ferreira Gomes (PSB). A questão do investimento feito em um candidato surge na fala do pesquisado: “(..) me dediquei a um candidato que era do PSDB e tudo, e quando entrou na prefeitura foi um verdadeiro desastre. Ele terminou sendo cooptado pelo governo e virando adversário político" (MOURÃO, 2012a, p.74).

Ao investir tempo, dinheiro e prestígio em um candidato, o doador espera o retorno desse não necessariamente material, mas de algo de valor social equivalente. Marcel Mauss (1974) descreveu uma dinâmica relacional semelhante a esta por meio do texto "Ensaio sobre a dádiva", no qual percebe que a comercialização de objetos entre os grupos sociais estabelece vínculos entre eles, e estes vínculos geram obrigações morais e fidelidades mútuas. O que está em jogo no relato do pesquisado não é somente o investimento material feito, mas também aspectos simbólicos, como o apoio dado na campanha, a ajuda na organização dos comícios, a "costura" das alianças com líderes locais para auxiliar na eleição do candidato apoiado, ou seja, o investimento do capital político da candidatura.

Podemos interpretar essas rupturas nas relações entre as lideranças municipais apoiadas e a família Figueiredo de Paula Pessoa a partir da lógica dos "objetivos em jogo" (BOURDIEU, 2007a). Um exemplo concreto dos conflitos ocasionados pelos objetivos do jogo político pode ser observado na relação entre esses dois grupos políticos, a família Ferreira Gomes e a 
família Figueiredo de Paula Pessoa. Em 1996, Cid Gomes venceu a disputa eleitoral contra Cândida Figueiredo pela Prefeitura de Sobral, dessa forma é possível ter surgido uma rixa política entre eles. Devemos também avaliar as posições ocupadas no campo político pelos agentes envolvidos no momento histórico em que Tomás Filho foi deputado. A família Figueiredo de Paula Pessoa se encontrava em posição oposta ao grupo que comandava o Governo do Estado naquele momento, os Ferreira Gomes ${ }^{21}$, e pela lógica da reciprocidade na política estadual, quem apoiasse o mandatário do governo teria mais chances de conseguir que seus pleitos fossem atendidos (BEZERRA, 1999). O conflito entre a fidelidade aos eleitores e a um determinado partido ou grupo político traz à tona os meandros no jogo político local, a captação de recursos para efetivar obras nos municípios onde se localizam as bases eleitorais e para a manutenção da legitimidade desse modelo de representação política.

\section{Conclusão}

Nesse sentido, mais que considerar a obtenção de voto como resultado imediato das capacidades individuais do candidato, ou como associado a variáveis estruturais, como aumento populacional, aumento da consciência política e do número de candidatos, a etnografia aqui produzida possibilita problematizar a produção, o desenvolvimento e a eficácia da campanha de Tomás Filho como resultado da mobilização de uma série de capitais, redes de parentescos e recursos que extrapolam a explicação institucional das normas que regem a disputa eleitoral e também as explicações estruturais já citadas.

Longe de ser um "passe de mágica", "dom" ou resultado de um automatismo estrutural, tanto a produção da campanha do deputado estudado como a distribuição de sua base eleitoral são, antes de tudo,

${ }^{21}$ Os Ferreira Gomes são uma família marcada pela tradição política no Ceará, sendo seus expoentes na atualidade os irmãos Cid, Ciro, Ivo Ferreira Gomes. Atualmente Cid é governador do Ceará, ex-deputado estadual e ex-prefeito de Sobral, Ciro é ex-prefeito de Fortaleza, ex-deputado federal e estadual, ex-governador, ex-ministro, Ivo é ex-prefeito de Sobral, ex-secretário de educação municipal, na época chefe de gabinete no governo do irmão e deputado estadual licenciado. 
fabricadas socialmente por meio da construção de classificações a respeito do parlamentar mais novo do Ceará, por meio da mobilização da estrutura familiar e de um conjunto de repertórios de intervenção política sustentados sobre determinadas redes de relações pessoais, mediações, laços de confiança e acúmulo de capitais, culturais, econômico e político.

Além de ser um receptor ou herdeiro dos habitus primários e secundários, demonstrou-se que a transmissão de poder social e político ocorreu também por meio de uma estrutura complexa na qual a organização familiar é um elemento constante e presente durante a trajetória do agente, não se restringindo apenas aos processos primários de inculcação. Assim, considerarem-se, separadamente, variáveis como os recursos econômicos, capital social e a forma como o agente mobiliza publicamente sua própria imagem possibilitou perceber uma estratégia de equalizar, ora obscurecendo, ora enfatizando aspectos das relações de parentesco e de mediação que evidenciam o vínculo de interdependência entre o parlamentar e suas bases locais, no presente e em outras temporalidades.

Enfim, considerando, antes de tudo, uma suspensão fenomenológica sobre as classificações e percepções dos agentes inseridos no recorte analisado, a etnografia desenvolvida demonstrou a campanha política por meio de uma lógica de reprodução política familiar que nos permitiu analisar o processo social pelo qual a campanha política do parlamentar desconcentrava-se do interior do estado e projetava-se para a Capital. Apontou também que o empreendimento eleitoral pode ser compreendido como atravessado por diferentes lógicas expressadas tanto nos âmbitos de instituições como família e órgãos estatais de normatização da competição política quanto de um conjunto de práticas que apontam para uma rica possibilidade de análise microssociológica pautada no método etnográfico e na abordagem sobre o cotidiano.

\section{Referências}

BARREIRA, César.

(2006a). Fraudes e Corrupções Eleitorais: entre dádivas e contravenções. In: Moacyr Palmeira; César Barreira (Orgs.); Política no Brasil: visões de antropólogos. Rio de Janeiro, Relume Dumará.
BARREIRA, Irlys.

(2006b). Campanha em família: as veias abertas das disputas eleitorais. In: Moacyr Palmeira; César Barreira (Orgs.); Política no Brasil: visões de antropólogos. Rio de Janeiro, Relume Dumará. 
BEZERRA, Marco Otávio.

(1999). Em nome das bases: políticas, favor e dependência social. Rio de Janeiro: RelumeDumará / NuAP - Coleção Antropologia da Política.

BOURDIEU, Pierre.

(2008). Os ritos de instituição. In: Pierre Bourdieu; A Economia das trocas simbólicas: o que falar quer dizer 2ed. São Paulo, Editora da Universidade de São Paulo.

(2007a). O Poder Simbólico. Rio de Janeiro, Bertrand Brasil.

(2007b). A Distinção: crítica social do julgamento. São Paulo / Porto Alegre, Edusp / Zouk.

(1999). A Miséria do Mundo. Petrópolis, Ed. Vozes.

CANEDO, Letícia Bicalho.

(1994). Caminhos da memória: parentesco e poder. Textos de História, Brasília, v. 2, n.3, p. 85-123.

\section{CEARÁ.}

(2011). Assembléia Legislativa. Memorial Pontes Neto. Mulheres no Parlamento Cearense / Coordenação Osmar Maia Diógenes. Fortaleza, INESP.

\section{CEARÁ.}

(2003). Assembléia Legislativa. Memorial Deputado Pontes Neto: Deputados Estaduais: 21 ${ }^{\text {a }}$ Legislatura 1983-1986. _Fortaleza, Editora INESP.

FIGUEIREDO FILH0. Tomás.

(2010). Tomás Figueiredo 4545. Disponível em:

https://www.flickr.com/people/ tomasfigueiredo4545/. Acesso em 24 de fevereiro de 2018.

GRILL, Igor Gastal.

(2008). Múltiplas dimensões de uma agenda comum de pesquisas: elites, profissionais e lideranças políticas. In: Igor Gastal Grill; Elisa Tavares dos Reis; e José Barros Filho (Orgs.); Elites, profissionais e lideranças políticas (RS e $M A)$ : pesquisas recentes. São Luís, EDUFMA. $276 \mathrm{p}$.
(2004). As Bases das Heranças Políticas no Rio Grande do Sul: Parentesco, Redes e Partidos. Sociedade em Debate (UCPel), Pelotas/RS, v. 10, n.2. p. 159-197.

(2005). Parentesco e Política no Rio Grande do Sul. Antropolítica (UFF), Rio de Janeiro/RJ, v. № 18. p. 127-150.

KUSCHNIR, Karina.

(2000). 0 cotidiano da política. Rio de Janeiro, Jorge Zahar.

LANDÉ, Carl H.

(1977). A base diádica do clientelismo. In: Steffen Schmidt; James Scott; Carl Landé; Laura Gausti (Eds.); Friends, followers and factions. Berkeley, University of California Press. (versão traduzida e datilografada em português).

MAYER, A. C.

(2010). A importância dos quase-grupos no estudo das sociedades complexas. In: FELDMAN-BIANCO, B. (Org.); Antropologia das sociedades contemporâneas. São Paulo, Global. p. 139-170.

MAUSS, Marcel.

(1974). Ensaio sobre a dádiva. Forma e razão da troca nas sociedades arcaicas. In: Sociologia e Antropologia. v. II. São Paulo, Edusp.

MOURÃO. Pedro Jorge; PEREIRA, Jesus Marmanillo.

(2012a). Os ancestrais e a infância: elementos primários da formação do habitus político. Opsis, v. 12, p.70-106.

MOURÃ0, Pedro Jorge Chaves.

(2012b). A socioanálise da formação de um deputado estadual: o casoTomás Figueiredo Filho. Dissertação (Mestrado). 2012 Programa de Pós-Graduação emSociologia. Universidade Federal do Ceará, Fortaleza. Disponivel em: <http://www.teses.ufc.br/ tde_busca/arquivo.php? codArquivo=8209>. Acesso em fevereiro de 2018.

PAIVA MORORÓ, Antônio Mauro.

(2006). História de Santa Quitéria. Santa Quitéria: Editora Artegráfica Ltda. Disponível 
em: $\quad<$ hhttp://www.paivamororo.com.br/ livros/livro_sq_historia_p1.pdf>. Acesso em 06 de junho de 2010.

REIS, Eliana Tavares dos.

(2015). Trajetórias e repertórios de intervenção política: um estudo sobre militantes que lutaram contra a ditadura no Rio Grande do Sul. Porto Alegre / Maranhão, EDUFMA / Ozouk.

SANTOS, Arnaldo; LEITÃo, Juarez. (2002). Verbo Cívico: Visão histórica-sociológica da Assembleia Legislativa do Ceará. Fortaleza, Expert Editora.

SCHERER-WARREN, ILSE.

(1995). Metodologia de redes do estudo das ações coletivas e movimentos sociais. In: VI Encontro Nacional da ANPUR.
WEBER, Max.

(2006). Ciência e política: Duas Vocações. São Paulo, Martin Claret.

WOLF, E.

(2003). Parentesco, amizade e relações patrono-cliente em sociedades complexas. In: Bela FELDMAN-BIANCo; Gustavo Lins Ribeiro (Orgs.); Antropologia e poder. Contribuições de Eric Wolf. Brasília / São Paulo / Campinas; Editora da Universidade de Brasília / Imprensa Oficial do Estado de São Paulo / Editora da Unicamp.

\section{Recebido em}

maio de 2016

Aprovado em

maio de 2018 